\title{
Stać przed zagadkami świata i życia ludzkiego bez gotowych odpowiedzi. O pisaniu biografii (nie tylko) Jana Potockiego
}

Z François Rossetem rozmawia Jerzy Borowczyk ${ }^{1}$

Gtówne tematy Pańskiej pracy naukowej (pisarskiej i dydaktycznej) to XVIII-wieczna powieść francuska, a także życie oraz dzieło Jana Potockiego. Zajmuje Pana w tym pisarstwie m. in. problematyka autobiografizmu, podróży, fantastyki. Jaki wplyw mialy utwory z tamtej epoki na Pański warsztat biograficzny? Pytam o to oczywiście w kontekście niezwykle ważnej i inspirującej biografii Potockiego wydanej najpierw po francusku w 2004 roku, a dwa lata później po polsku (w przekładzie Anny Wasilewskiej), którą napisał Pan wespół z Dominique'em Triaire'em.

Bardzo słusznie łączy Pan gruntowną pracę badawczą i dydaktyczną nad europejską powieścią szeroko pojętego Oświecenia z pisaniem biografii Potockiego. W XVIII wieku autorzy znacznie rozszerzają wachlarz form subiektywnego dyskursu. Nie tylko w powieściach-pamiętnikach, w powieściach epistolarnych, w powieściach szkatułkowych, ale także w przedłużeniu barokowych wzorców, jak np. w hiszpańskich powieściach pikarejskich 
(czy łotrzykowskich) pojawia się coraz wyraźniej jako centralna oś fabularna model życia wybranej jednostki. Model prastary, ale teraz już jakby odmitologizowany, sprowadzony do rzeczywistości ludzkiego życia. Te powieści poniekąd są biografiami, oczywiście fikcyjnymi, ale podstawowe pytania przez nie stawiane wcale nie odbiegają od zadań i problemów, z którymi mierzy się autor „prawdziwej” biografii: jak ustosunkować się - w toku poszukiwań spójnej i całościowej formuły biograficznej - do przypadków i koniunkturalizmu losów danej jednostki, kierowanej lub nie przez nadrzędną siłę i niezależnie od tego, czy tą siłą jest opatrzność, czy po prostu ludzki mózg, w którym te przypadki układają się w czytelną całość? Jak łączyć kolejność wypadków, czyli jakie jest miejsce przyczynowości? Na czym polega budowanie osi aksjologicznej, której dana postać jest przedstawicielem, czy nawet uosobieniem? Jaka jest różnica między opowiadanym a przeżywanym naprawdę życiem? Będąc wyposażonym (obciążonym?) w taki zestaw pytań, podchodzi się do pisania biografii z najwyższym stopniem ostrożności. Z nich bowiem wynika kłopotliwa prawda: nie ma zasadniczej różnicy między opowiadaniem fikcyjnego i prawdziwego życia ludzkiego.

W przedmowie do biografii autora „Parad” podkreślaja Panowie, $\dot{z} e$ wszelkie opinie oparte zostaty na dokumentach. Da się zauważyć $w$ toku lektury dbatość o dystans wobec swego bohatera i narracyjna (beletryzacyjna) wstrzemięźliwość. Podkreślat to także Janusz Ryba w recenzji francuskiego pierwodruku książki Panów („Pamiętnik Literacki" 2007, z. 2, s. 219-223). Skąd takie nastawienie? Czy jest to skutek wymogu naukowego obiektywizmu? Efekt potężnej rozmaitości wynikającej z losów i twórczości Potockiego? Nie korciło Pana, by mocniej zaangażować się w opowieść o kimś, kto ewidentnie Pana fascynuje (wyczuwa się to $w$ wielu partiach tej biografii)?

Trzeba najpierw wyjaśnić, w jakich okolicznościach powstała ta biografia. Nie mieliśmy wcale zamiaru napisania jej. Pracowaliśmy nad sześciotomowym wydaniem dzieł, które nabrało bardzo ostrych rysów po odkryciu w Poznaniu przez Triaire'a nieznanych do tej pory manuskryptów Rękopisu znalezionego w Sara- 
gossie. Seria została opublikowana między 2004 a 2006 rokiem w Leuven u Peetersa. Pracowaliśmy nad nią od jesieni 2000 roku. Tymczasem w 2003 roku redaktor naczelna wielkiego koncernu wydawniczego Flammarion w Paryżu zwróciła się do nas z propozycją napisania biografii Potockiego - ale od razu. Propozycja przyszła w bardzo kłopotliwym momencie, jednak była nie do odrzucenia. To była wielka szansa na szersze wyeksponowanie tej niezwykłej, a jednak mało znanej postaci. Należało więc podwoić wysiłki. Dziś nie bardzo sobie wyobrażam, jak stało się to możliwe (tym bardziej, że przez ten cały czas ciążyły nam także liczne obowiązki na uczelniach), ale jakoś poradziliśmy sobie i z wydaniem dzieł, i z biografią.

Opowiadam o tym, by podkreślić raz jeszcze, że biografia przyszła jako dodatek do pracy filologicznej, a nie odwrotnie. Dlatego stało się możliwe dopasowanie zasad pisania biografii do etosu pracy naukowej. Było od początku jasne, że nie będziemy łatać braków w dokumentacji i wiedzy, mobilizując wyobraźnię. Każde stwierdzenie musiało mieć pokrycie w dokumentacji, a gdy pojawiały się luki, to jedynie proponowaliśmy zestaw najbardziej prawdopodobnych hipotez. Zresztą to, co wiemy (i fakt, że udało się znacznie rozszerzyć tę wiedzę, dzięki pracom nad biografią), jest już wystarczająco ciekawe i barwne, by móc zainteresować każdego czytelnika. Oczywiście nie rezygnowaliśmy z okazji do spektakularnych opowieści, gdy się tylko pojawiały, jak np. epizod lotu balonem nad Warszawą w maju 1790 roku, który zebrane źródła pozwalają odtworzyć dość szczegółowo i w tonacji wyraźnie heroikomicznej. W naszej książce można natrafić także na bardziej brawurowe kawałki i nie ukrywam, że były to szczególnie podniecające momenty podczas pisania, jednak nic w nich nie jest przez nas wymyślone. Zresztą nie znaczy to, że wszystko, co znajduje się w źródłach, jest zgodne z faktami. Przecież do źródeł też trzeba podchodzić ostrożnie i staraliśmy się tę ostrożność nie tylko zachować, ale także dać ją odczuć czytelnikowi.

Przyznaję bez wstydu, że postać Potockiego rzeczywiście mnie fascynuje. Zresztą bez tej fascynacji nie byłoby zapewne tej energii i determinacji do dokonania tak dużej pracy w stosunkowo krótkim czasie. Ale w samej pracy staraliśmy się tę fascynację kon- 
trolować. Od początku było oczywiste, że nie piszemy ani hagiografii, ani podstawy do rehabilitacji zapomnianego bohatera. Wielkość Potockiego i tak nie wynika z bohaterskiej postawy i w ogóle poetyka bohaterska byłaby zupełnie nie na miejscu. Wielkość Potockiego wyraża się właśnie w jego słabościach, przy niezwykłych zdolnościach intelektualnych i poznawczych oraz wyjątkowo wyostrzonej wrażliwości. Stanął przed zagadkami świata i życia ludzkiego bez gotowych odpowiedzi, sam borykając się ze sprzecznościami, paradoksami, niejasnościami, absurdem. W toku zmagań z trudnościami starał się dać świadectwo człowieka uczciwie poszukującego odpowiedzi na najbardziej zagadkowe pytania, i ciężko nad tym pracowal, jak melancholijny Tytan albo dowcipny Syzyf, aż w końcu nie wytrzymał. Chcieliśmy opowiadać o tym tragicznym życiorysie bez patosu i - o ile było to możliwie - bez widocznego podziwu, zachowując świadomość, że odtwarzamy drogę życia, która więcej stawia pytań, niż dostarcza odpowiedzi.

Zanim zasiadt Pan - wraz z Triaire'em - do pisania biografii Potockiego, wiele lat poświęcit Pan badaniom nad (jakby powiedzieli badacze z paryskiego ITEM) dossier genezy i samym procesem tekstotwórczym "Rękopisu znalezionego w Saragossie”. Na ile dociekania tekstologiczne i edytorskie decyzje wplynęty na koncepcję i sposób pisania o życiu i twórczości Potockiego?

Wiadomo, że pisanie biografii pisarzy jest szczególnie trudne, tym bardziej jeśli są to autorzy, którzy sami opowiadali o własnym życiu w swoich utworach. Na przykład dla biografów Jana Jakuba Rousseau materiałem bardzo zdradliwym są Wyznania i jest fatalną pokusą traktowanie tego genialnego tekstu jako wiarygodnego dokumentu do opowiadania o życiu jego twórcy. Potocki nie należał do tej kategorii autorów, choć w pewnym sensie jego relacje z podróży mają wyraźny charakter autobiograficzny i dostarczają obfitych informacji o tych licznych i ważnych epizodach w jego życiu. Trzeba jednak traktować ten materiał z rezerwą, pamiętając o tym, że nie jest przeźroczystą dokumentacją o faktach, lecz przefiltrowaną i spreparowaną, naznaczoną różnorodnymi uwarunkowaniami narracją. Jednym słowem, w tekstach pisarzy wymiaru 
samej treści nie powinno się traktować naiwnie jako zapisu tego, co „naprawdę” zaszło. Inaczej jest z formą tekstów. Jak się ma do dyspozycji bogaty materiał świadczący o genezie utworów, to można dzięki niemu bardzo wiele zrozumieć, nie tylko jeśli chodzi o etapy rozwoju zamysłu tego utworu i jego stopniowych przekształceń, lecz także w kontekście tego, jak funkcjonował dany umysł. Historia tekstów może być bardziej wymowna co do charakteru i idiosynkrazji danego pisarza niż jego czyny w świecie. I rzeczywiście, praca nad ustaleniem tekstów o bujnej historii, rozwarstwionych wersjach świadczących o stałym niepokoju autora co do właściwej struktury organizacyjnej i formy, dostarcza wielu danych pozwalających na lepsze zrozumienie przekonań i wątpliwości danego autora w sprawach nie tylko estetycznych i literackich, ale także filozoficznych, moralnych, politycznych i epistemologicznych. Na pytanie: kim jest autor? - historia przekształceń jego tekstów proponuje odpowiedzi, których trudno się doszukiwać w innego rodzaju dokumentacji.

Przekonaliśmy się o tym bardzo głęboko, śledząc kolejne wersje różnych tekstów Potockiego, z Rękopisem znalezionym $w$ Saragossie na czele. Badając z bliska dwadzieścia dwa dokumenty źródłowe tej powieści, ustalając na ich podstawie ćwierćwiekową historię powstawania i przemian tekstu, zrozumieliśmy bardzo wiele nie tylko z samej powieści, ale także z życiorysu protagonisty tej długiej i mozolnej pracy twórczej. Na tym tle Potocki ujawnia się jako niespokojny umysł, dążący uparcie do znalezienia najwłaściwszej formy dla zamierzonego przekazu, choć wie od początku, że w pełni zadowalającej formy nie znajdzie. Zestawia więc przeciwstawne koncepcje, próbuje jedną i drugą, i jeszcze następną, mnoży exempla, które pokazują przeróżne i równie bezskuteczne sposoby dotarcia do wiedzy nadrzędnej, przywołuje kolejne figury, z których potem rezygnuje albo które zastępuje innymi (typowy przykład: zniknięcie historii Żyda wiecznego tułacza w ostatniej chronologicznie wersji powieści), zmienia akcenty, które mogłyby pozwolić na ustalenie pewnej hierarchii w proponowanych drogach poznawczych i systemach filozoficznych. Dochodzi do przekonania, że nie ma podstaw do solidnych wniosków, lecz nie jest to cyniczne stwierdzenie, które pozwala żyć z szyderczym dystansem 
do wszystkiego. Przekonanie to jest dramatycznym doświadczeniem niestrudzonego badacza, który mimo wszystko odczuwa moralny przymus dalszego, choć beznadziejnego poszukiwania na ile tylko starczy sił. Podobną postawę znajdujemy w pracach naukowych Potockiego, w sposobie funkcjonowania w społeczeństwie, towarzystwie i rodzinie, w zaangażowaniu politycznym, w krótkotrwałych porywach ideowych. Jego portret wychodzi najlepiej na tle jego stale niedokończonych brulionów.

Chciałbym zapytać o fazy pracy nad biografia Potockiego. Książka ma mocny fundament źródłowy - odbyli Panowie wiele archiwalnych kwerend, musieli się też Panowie zmagaćz obszernym korpusem dziet i ich różnorodnością. Czy oddzielaliście wyraźnie fazę pracy dokumentacyjnej i pisarskiej, czy też biegły one równolegle?

Gdy zabraliśmy się do pisania biografii, mieliśmy już za sobą długie i głębokie obcowanie z tekstami Potockiego, a także solidną znajomość zarówno kontekstu historycznego, jak i literackiego krajobrazu, w którym autor się poruszał i w który się wpisywał. Znaliśmy stosunkowo dobrze, pośrednio lub bezpośrednio, gigantyczny obszar jego erudycji, tradycje filozoficzne, literackie, mitologiczne, historiograficzne, do których stale się odnosił, wzbogacając je o kolejne dzieła. Wydawało się, że jesteśmy nieźle przygotowani i dlatego zresztą podjęliśmy to wyzwanie bez dłuższego zastanawiania się. Bez większych problemów ustaliliśmy także ogólną strukturę biografii. Tymczasem gdy zaczęliśmy pisać, okazało się, że nasza wiedza jest jednak bardzo wybrakowana i że nie możemy co rusz tłumaczyć czytelnikowi, że na taki lub inny temat nic nie wiadomo. Ruszyliśmy więc na kolejne poszukiwania w archiwach francuskich, szwajcarskich, austriackich, niemieckich, polskich, ukraińskich, litewskich, rosyjskich. Każda kampania przynosiła nowe, mniej lub bardziej istotne informacje, potwierdzając lub obalając wcześniej stawiane hipotezy, prostując powielane od dawna błędne przekazy, wzbogacając w znacznej mierze zestaw materiałów. Wiadomo było, że kontynuując kwerendy, znajdziemy jeszcze to i tamto - co zresztą się potwierdziło po latach - ale mieliśmy ustalony przez wydawcę termin oddania książki i w pewnym 
momencie trzeba było sobie powiedzieć: stop! Gdyby miało się pojawić nowe wydanie tej biografii, byłoby to i owo do poprawienia oraz nieco uzupełnień do wprowadzenia, ale tak naprawdę nic szczególnie istotnego, a w każdym razie nic, co miałoby zmienić tonację proponowanego portretu Potockiego.

Ciekawi mnie także, jak pisze się biografię $w$ duecie. Wcześniej obaj Panowie wydali tom szkiców i studiów „Z Warszawy do Saragossy. Jan Potocki i jego dzieło" (Warszawa 2005), w którym wyraźnie jednak zaznaczono autorstwo poszczególnych prac. Natomiast w przypadku „Jana Potockiego. Biografi" mamy do czynienia z książka wspólną. Jak to wygladało w praktyce? Wspólne pisanie, czy jedynie rozmowy, a potem każdy pisat samodzielnie? Dzieliliście się Panowie różnymi obszarami życia i twórczości Potockiego, czy też nad każdym elementem pracowaliście wspólnie?

Największy komplement, jaki usłyszeliśmy od pani redaktor naczelnej w wydawnictwie Flammarion, to stwierdzenie, że nie była w stanie rozróżnić, co napisał Triaire, a co Rosset. W wersji polskiej, ponieważ całość jest przetłumaczona przez jedną osobę, obserwacja taka byłaby mniej wymowna. Konkretnie to wyglądało tak: zdecydowaliśmy się podzielić chronologicznie życiorys Potockiego na osiem faz, które miały stanowić kolejne, ułożone chronologicznie rozdziały. Podzieliliśmy te rozdziały po cztery dla każdego, biorąc pod uwagę oczywiście stan wiedzy, osobiste zainteresowania i kompetencje każdego z nas. Okazało się, że te charakterystyki bardzo dobrze się uzupełniały. Dominique znał znacznie lepiej zarówno tło historyczne oraz wątki polityczne, jak i całą myśl wschodnią Potockiego. Ja się jako tako nadawałem do innych spraw. Oczywiście z biegiem pracy okazało się, że w każdym rozdziale pisanym przez jednego drugi miał także coś do powiedzenia. Bruliony kursowały więc bez przerwy między Montpellier a Lozanną. Dochodziły poprawki, uzupełnienia, niuanse. Nawet stylistycznie doszło do obopólnych wpływów. Dominique „triairyzował” moje teksty, ja „rossetyzowałem” jego i w ten sposób doszło - choć nie było to zupełnie ani zamierzone, ani systematycznie prowadzone - do nastrojenia naszego wspólnego 
głosu. Myślę, że taka współpraca jest możliwa tylko przy gębokiej obopólnej znajomości i nawet przyjaźni, przy dobrze uzupełniających się mocnych stronach, przy pełnym zaufaniu, i - co chyba najważniejsze - przy braku dumy albo wręcz pychy autorskiej zarówno u jednego, jak i drugiego.

Który z okresów życia Potockiego nastręczyt Panu najwięcej trudności? $Z$ którymi dokumentami pracowało się najciężej?

Najciężej pracuje się z dokumentami... których nie ma! O tym już mówiliśmy, ale sytuacja odwrotna też bywa kłopotliwa. Tak jest z podróżami, które należy opowiadać syntetycznie, wybierając najbardziej znaczące elementy, kiedy dokumentacja kusi do drobiazgowej narracji. Problemem są także wspaniałe i obszerne, zupełnie nieznane i nowo odkryte dokumenty źródłowe. Jest chęć, by te dokumenty jakoś wypromować, obszernie zacytować. Daliśmy nieraz tej chęci upust, ale naprawdę się pilnowaliśmy, by nie zanudzać czytelnika. Największe odstępstwo od tej wstrzemięźliwości zrobiliśmy przy zacytowaniu opisu wizyty doktora Josepha Franka u chorej Konstancji (drugiej żony Potockiego) w styczniu 1811 roku. Jest to świadectwo tak niesamowite, że znalazło się dla niego miejsce na dwóch pełnych stronach biografii (strony 407$409 \mathrm{w}$ wydaniu polskim). Inna rzecz, że ten dokument (znaleziony w Bibliotece Uniwersyteckiej w Wilnie) dotyczy najgorzej znanego i najtrudniejszego okresu życia Potockiego - zarówno dla niego samego, jak i dla jego biografów. Pisarz przebywa wówczas w samotności w Uładówce na Podolu, pogrążony w melancholii, a zarazem obsesyjnie zajęty pracami nad powszechną chronologią oraz nad Rękopisem znalezionym $w$ Saragossie. O tych ostatnich latach jest bardzo mało informacji, a ponieważ kończą się one tragicznym gestem samobójczym, na dodatek wywyższonym do statusu czarnej legendy, to trudno jest zachować dystans, obronić się przed teleologicznym odczytywaniem tych smutnych lat, w czasie których przecież wiele się działo, choć nie wiadomo dokładnie co.

Czy mógłby Pan wskazać prace biograficzne i autorów biografii, od których najwięcej się Pan nauczyt? Chodziłoby zarówno o wzorce, 
które mniej czy bardziej Pan akceptuje, jak i o takie dokonania, z którymi chcialby Pan polemizować?

Miałbym ochotę wymigać się przed tym pytaniem, zasłaniając się tym - co zresztą stwierdzam bez żadnej kokieterii - że nie jestem specjalistą od biografii. Biografię jedną napisałem (i to do spółki) jakby przypadkowo, na zamówienie, nie mając do tego żadnego warsztatowego przygotowania, jedynie stosunkowo dobrą znajomość przedmiotu i w miarę przyzwoite doświadczenie literackie. Biografie czytałem, ale bez szczególnej pasji do tego gatunku. Dopiero znajdując się w sytuacji tego biografa amatora, zdałem sobie sprawę z wagi problemów, które ten gatunek z sobą niesie. Ściślej mówiąc, do tej świadomości dotarlem tak naprawdę po napisaniu książki. Wtedy postanowiłem prowadzić ze studentami seminarium magisterskie o biografii pisarzy. I tu zdobyłem już trochę szerszą wizję problemu.

Odpowiem jednak na postawione pytanie. Otóż nie poważam braku rzetelności we wszystkim, a więc i w biografiach. Biografia, która jest tylko przełożeniem na strukturę narracyjną wiedzy już ogólnie dostępniej, nie interesuje mnie. Musi mieć wartość dodaną w postaci nowych, odnalezionych dokumentów, nowych propozycji poznawczych opartych na solidnym przygotowaniu. Zresztą podobne wymagania stawiam pisarzom, którzy piszą powieści zakorzenione w historii (świetny przykład z ostatnich lat: Księgi jakubowe Olgi Tokarczuk). Wszystkie romansiki biograficzne mają oczywiście prawo bytu i dobrze, że mają swoją publiczność, ale rozumiem, że jestem pytany o własne zdanie. Nie gustuję też specjalnie w biografiach profesorów, którzy traktują to pisanie jako miłą odskocznię od mozolnej pracy naukowej, jako wakacyjne zajęcie, które charakteryzuje się na ogól pewnym stylistycznym folgowaniem sobie, często sąsiadującym ze złym gustem. Jest np. taka biografia Rousseau napisana przez znanego profesora belgijskiego, w której wszystko jest podane zgodnie z panująca, najgłębszą wiedzą, ale z taką dość irytującą manierą pseudopisarską. Nie lubię także biografii prokuratorskich, w których celem jest obalenie jakiegoś autorytetu poprzez wytykanie takich czy innych słabości. Na ogół demitologizacja jest równie naiwna jak mito- 
logizacja. Problematyczny jest dla mnie także model tzw. amerykańskiej biografii, według którego należy wykładać dosłownie wszystko, co się wie. Przecież i tak nigdy wszystkiego się nie wie, a w gąszczu faktów traci się to, co ważne. Na szczęście jest dużo dobrych osiągnięć w dziedzinie biografii, czy to w konwencji eleganckiej, literackiej opowieści (np. biografia Stanisława Augusta Poniatowskiego napisana przez Józefa Hena), czy to w postaci solidnych opracowań dziennikarskich (np. biografia Czesława Miłosza napisana przez Andrzeja Franaszka). Gdzie piórem kierują rzetelność, elegancja i pokora, tam są wszelkie szanse na porządną biografię.

Jerzy Borowczyk

To stand before the riddles of the world and human life without ready answers. About writing a biography (not only) of Jan Potocki. Jerzy Borowczyk talks with François Rosset

The conversation concerns the broadly-understood methodological background and substantive knowledge of the co-author of the highly praised biography of Jan Potocki, François Rosset. The researcher talks about the importance and usefulness of knowledge of the French eighteen-century novel, the Enlightenment ideas and artistic trends for the work on the biography of the author of The Manuscript found in Saragossa. Rosset also talks about archive research related to the work on this biography and about how he used his knowledge of editorial meanders of the famous novel while writing. The researcher emphasizes that the authors of biographies should keep a distance from the characters of their stories and that their main goal is to try to present the life cycle of a given person as comprehensively as possible, supporting it with sources.

Keywords: French novel in the eighteenth century; travel theme; biography of Jan Potocki; autobiographism; contemporary literary biographies; editing; genetics of text. 
Jerzy Borowczyk - doktor habilitowany, historyk literatury, zatrudniony w Instytucie Filologii Polskiej Uniwersytetu im. Adama Mickiewicza w Poznaniu. Zajmuje się romantyzmem, któremu poświęcił dwie książki: Rekonstrukcja procesu filomatów i filaretów 1823-1824 (2003) oraz Zesłane pokolenie. Filomaci w Rosji 1824-1870 (2014). Współredaktor kilku tomów zbiorowych poświęconych literaturze i kulturze XIX wieku. Pisuje również w czasopismach, książkach zbiorowych oraz w tomie szkiców Po chwiejnym trapie (2016) - o literaturze Xx wieku i najnowszej. Publikuje w „Czasie Kultury”, „Pamiętniku Literackim”, „Przeglądzie Humanistycznym”. Wspólnie z Michałem Larkiem nagrali i zapisali tomy wywiadów z pisarzami, reporterami i politykami (Rozmowa była możliwa, 2008; Przywracanie, wracanie. Rozmowy szczecińskie z Arturem Danielem Liskowackim, 2014; Punkty zapalne. Dwanaście rozmów o Polsce i świecie, 2016) oraz ułożyli antologię polskiej liryki nowoczesnej (Powiedzieć to inaczej, 2011). Wraz z Zofią Dambek-Giallelis i Elżbietą Lijewską wydał przewodnik literacki Na tropach Adama Mickiewicza w Wielkopolsce (2013). Z kolei razem z Wojciechem Hamerskim ułożył książkę Co piłka robi z człowiekiem? Młodość, futbol i literatura - antologia (2012). Współpracownik Redakcji „Czasu Kultury” oraz członek Kolegium Redakcyjnego „Kroniki Miasta Poznania”.

François Rosset - profesor literatury francuskiej na Uniwersytecie w Lozannie. Zajmuje się literaturą francuską XVIII (utwory pisarzy związanych z tzw. Groupe de Coppet - Madame de Staël, Banjamin Constant, Jean de Sismondi) i XIX wieku (twórczość i biografia Jana Potockiego). Doktorat uzyskał na Uniwersytecie Jagiellońskim, następne etapy kariery naukowej związane są z lozańską uczelnią. W 1997 roku ukazało się polskie tłumaczenie jego książki Drzewo Kraków. Mit polski w literaturze francuskiej 1753-1896. Wspólnie z Dominique'em Triaire'em napisali zbiór szkiców poświęconych pisarstwu i życiu Jana Potockiego ( $Z$ Warszawy do Saragossy. Jan Potocki i jego dzieło, 2005), biografię tegoż (pol. wyd. 2006) oraz przygotowali nową edycję jego Rękopisu znalezionego w Saragossie na podstawie ostatniej wersji autorskiej z 1810 roku (pol. przekład Anny Wasilewskiej ukazał się w 2015 roku). Od lat jest prezesem Fundacji im. Kościelskich, która przyznaje Nagrodę Literacką Kościelskich. Przekładał na język francuski dzieła współczesnych pisarzy polskich - m.in. Andrzeja Szczypiorskiego i Pawła Huelle. 
